\title{
Anodic Behavior of Alloy 22 in Calcium Chloride and in Calcium Chloride plus Calcium Nitrate Brines
}

K. J. Evans, S. D. Day, G. O. Ilevbare, M. T. Whalen, K. J. King, G. A. Hust, L. A. Wong, J. C. Estill, R. B. Rebak

This article was submitted to 2003 American Society of Mechanical Engineers Pressure Vessels and Piping Conference, Cleveland, OH, July 20-24, 2003

U.S. Department of Energy

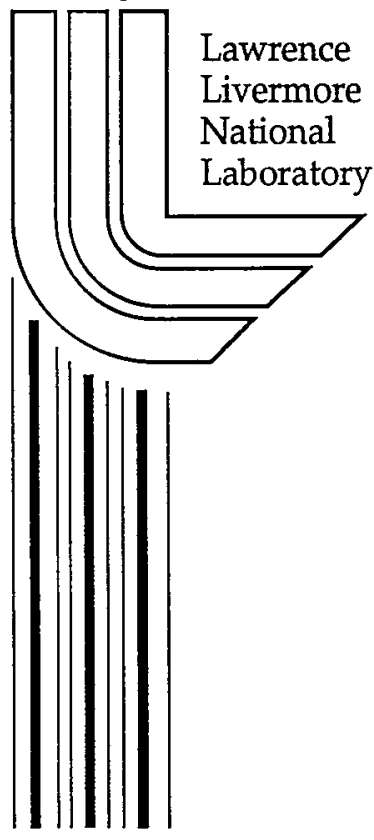

\section{May 13, 2003}


This document was prepared as an account of work sponsored by an agency of the United States Government. Neither the United States Government nor the University of California nor any of their employees, makes any warranty, express or implied, or assumes any legal liability or responsibility for the accuracy, completeness, or usefulness of any information, apparatus, product, or process disclosed, or represents that its use would not infringe privately owned rights. Reference herein to any specific commercial product, process, or service by trade name, trademark, manufacturer, or otherwise, does not necessarily constitute or imply its endorsement, recommendation, or favoring by the United States Government or the University of California. The views and opinions of authors expressed herein do not necessarily state or reflect those of the United States Government or the University of California, and shall not be used for advertising or product endorsement purposes.

This is a preprint of a paper intended for publication in a journal or proceedings. Since changes may be made before publication, this preprint is made available with the understanding that it will not be cited or reproduced without the permission of the author.

This work was performed under the auspices of the United States Department of Energy by the University of California, Lawrence Livermore National Laboratory under contract No. W-7405-Eng-48.

This report has been reproduced directly from the best available copy.

Available electronically at http://www.doc.gov/bridge

Available for a processing fee to U.S. Department of Energy

And its contractors in paper from

U.S. Department of Energy

Office of Scientific and Technical Information

P.O. Box 62

Oak Ridge, TN 37831-0062

Telephone: (865) 576-8401

Facsimile: (865) 576-5728

E-mail: reports@adonis.osti.gov

Available for the sale to the public from

U.S. Department of Commerce

National Technical Information Service

5285 Port Royal Road

Springfield, VA 22161

Telephone: (800) 553-6847

Facsimile: (703) 605-6900

E-mail: orders@ntis.fedworld.gov

Online ordering: http://www.ntis.gov/ordering.htm

OR

Lawrence Livermore National Laboratory

Technical Information Department's Digital Library

http://www.llnl.gov/tid/Library.html 
Paper prepared for presentation to the 2003 American Society of Mechanical Engineers Pressure Vessels and Piping Conference, 20-24 July in Cleveland

\title{
Anodic Behavior of Alloy 22 in Calcium Chloride and in Calcium Chloride plus Calcium Nitrate Brines
}

Kenneth J. Evans, S. Daniel Day, Gabriel O. Mlevbare, Michael T. Whalen, Kenneth J. King, Gary A. Hust, Lana L. Wong, John C. Estill and Raúl B. Rebak Lawrence Livermore National Laboratory, Livermore, CA 94550

\begin{abstract}
Alloy 22 (UNS N60622) is a nickel-based alloy, which is extensively used in aggressive industrial applications, especially due to its resistance to localized corrosion and stress corrosion cracking in high chloride environments. The purpose of this work was to characterize the anodic behavior of Alloy 22 in concentrated calcium chloride $\left(\mathrm{CaCl}_{2}\right)$ brines and to evaluate the inhibitive effect of nitrate, especially to localized corrosion. Standard electrochemical tests such as polarization resistance and cyclic polarization were used. Results show that the corrosion potential of Alloy 22 was approximately $-360 \mathrm{mV}$ in the silver-silver chloride (SSC) scale and independent of the tested temperature. Cyclic polarization tests showed that Alloy 22 was mainly susceptible to localized attack in $5 \mathrm{M}$ $\mathrm{CaCl}_{2}$ at $75^{\circ} \mathrm{C}$ and higher temperatures. The addition of nitrate in a molar ratio of chloride to nitrate equal to 10 increased the onset of localized corrosion to approximately $105^{\circ} \mathrm{C}$. The addition of nitrate to the solution also decreased the uniform corrosion rate and the passive current of the alloy.
\end{abstract}

\section{INTRODUCTION}

Alloy 22 or N06022 is nickel-based (Ni) and contains by weight $22 \%$ chromium (Cr), 13\% molybdenum (Mo), 3\% tungsten (W) and approximately 3\% iron (Fe). Alloy 22 was commercially designed to resist the most aggressive industrial applications, offering a low general corrosion rate both under oxidizing and reducing conditions. Under oxidizing and acidic conditions $\mathrm{Cr}$ exerts its beneficial effect in the alloy. Under reducing conditions the most beneficial alloying elements are Mo and W, which offer a low discharge current for hydrogen discharge [1]. Moreover, due to its balanced content in $\mathrm{Cr}$, Mo and W, Alloy 22 is used extensively in hot chloride containing environments where austenitic stainless steels may fail by pitting corrosion and stress corrosion cracking (SCC) $[1,2]$.

Alloy 22 is the material selected for the fabrication of the outer shell of the nuclear waste containers for the Yucca Mountain site $[3,4]$. Several papers have been published recently describing the general and localized corrosion behavior of Alloy 22 
regarding its application for the nuclear waste containers [5-14]. Some of these studies included the characterization of Alloy 22 to localized corrosion in chloride solutions such as in lithium chloride $(\mathrm{LiCl})$ [5], sodium chloride $(\mathrm{NaCl})$ [12-13] and calcium chloride $\left(\mathrm{CaCl}_{2}\right)$ [6-8]. It has also been reported that the addition of nitrate to a chloridecontaining environment, decreases the susceptibility of Alloy 22 to localized attack [4-6, 13].

The objective of the current study was to use electrochemical methods and parameters to systematically assess the corrosion behavior of Alloy 22 (N06022) in high chloride solutions as a function of the temperature and to evaluate the inhibitive effect of nitrate. It was of interest to investigate the corrosion behavior of Alloy 22 in a concentrated chloride solution. Since the solubility of $\mathrm{NaCl}$ is limited to approximately 4 $\mathrm{M}$ [4 $\left.\mathrm{M} \mathrm{Cl}^{-}\right]$from ambient to $100^{\circ} \mathrm{C}, \mathrm{CaCl}_{2}$ was selected. The most common solution for this study was $5 \mathrm{M} \mathrm{CaCl}_{2}$ [or $10 \mathrm{M} \mathrm{Cl}^{-}$]; however, studies were also carried out in up to 9 $\mathrm{M} \mathrm{CaCl}_{2}$ (or $18 \mathrm{M} \mathrm{Cl}^{-}$). Calcium Chloride $\left(\mathrm{CaCl}_{2}\right)$ has many common applications such as in ice melting, dust control (in unpaved roads), concrete acceleration and water treatment [15-16]. For example, as dust control agent, $\mathrm{CaCl}_{2}$ relies on its hygroscopic qualities, that is, it may be spread on unpaved roads where it attracts humidity from the air and keeps the dirt roads compact.

\section{EXPERIMENTAL}

Alloy 22 specimens were mainly prepared from wrought mill annealed plate stock. There were several heats of material used in this research. The basic chemical composition of Alloy 22 in weight percent was $-57 \% \mathrm{Ni}, 22 \% \mathrm{Cr}, 13 \% \mathrm{Mo}, 3 \% \mathrm{~W}, 3 \%$ $\mathrm{Fe},<1 \% \mathrm{Co}, 0.14 \% \mathrm{Mn}, 0.002 \% \mathrm{C}$, and $0.0001 \% \mathrm{~S}$. Alloy 22 was tested in the mill annealed (MA) or wrought condition and in the as-welded (ASW) condition. Most of the data analyzed here refer to the MA condition. Several different types of metallic specimens for electrochemical testing were used. Most of these specimens were multiple crevice assemblies (MCA), which were fabricated based on the washer for crevice forming described in ASTM G 48 [17]. The specimen MCA has been described before [5,7-8]. Other specimens were discs or prisms derived from specimens described in ASTM G 5 [17]. The prism specimen has also been described before [6]. The tested surface area of these specimens varied between $11 \mathrm{~cm}^{2}$ for the MCA to $0.7 \mathrm{~cm}^{2}$ for the discs. Most of the tested specimens had a finished grinding of abrasive paper number 600 and were degreased in acetone and treated ultrasonically for 5 minutes in de-ionized (DI) water 1 hour prior to testing.

Electrochemical tests were carried out in deaerated concentrated $\mathrm{CaCl}_{2}$ solutions and solutions containing both $\mathrm{CaCl}_{2}$ and $\mathrm{Ca}\left(\mathrm{NO}_{3}\right)_{2}$ in a molar ratio of chloride over nitrate of ten $\left(\left[\mathrm{Cl}^{-}\right] /\left[\mathrm{NO}_{3}{ }^{-}\right]=10\right)$. Most of the tests were conducted in $5 \mathrm{M} \mathrm{CaCl}_{2}$ (pH 6.4) and $5 \mathrm{M} \mathrm{CaCl}_{2}+0.5 \mathrm{M} \mathrm{Ca}\left(\mathrm{NO}_{3}\right)_{2}$ (pH 5.8). The most common tested temperatures were $45,60,75,90,105,120$ and $130^{\circ} \mathrm{C}$. Up to a temperature of $120^{\circ} \mathrm{C}$ most tests were conducted in $5 \mathrm{M} \mathrm{CaCl}_{2}$. At the higher temperatures the concentration of $\mathrm{CaCl}_{2}$ was raised to 7,8 and $9 \mathrm{M}$. Nitrogen $\left(\mathrm{N}_{2}\right)$ was purged through the solution at a flow rate of $100 \mathrm{cc} / \mathrm{min}$ for 24 hours while the corrosion potential $\left(E_{\text {corr }}\right)$ was monitored. After the recording of $E_{\text {corr }}$, three polarization resistance (PR) tests (ASTM G 59) [17] followed by one cyclic polarization (CP) test (ASTM G 61) [17] were conducted. Nitrogen bubbling 
was carried throughout all the electrochemical tests. The electrochemical tests were carried out in a one-liter, three-electrode, borosilicate glass flask (ASTM G 5) [17]. A water-cooled condenser combined with a water trap was used to maintain solution concentration and controlled atmosphere. Solution temperatures were controlled by immersing the cell in a thermostatisized silicone oil bath. All the tests were carried at ambient pressure. The reference electrode was saturated silver chloride (SSC) electrode, which has a potential of $199 \mathrm{mV}$ more positive than the standard hydrogen electrode (SHE). The reference electrode was connected to the solution through a water-jacketed Luggin probe so that the electrode was maintained at near ambient temperature. The counter electrode was a flag $\left(36 \mathrm{~cm}^{2}\right)$ of platinum foil spot-welded to a platinum wire. All the potentials in this paper are reported in the SSC scale.

Corrosion rates (CR) were obtained using the polarization resistance method (ASTM G 59) [17]. An initial potential of $20 \mathrm{mV}$ below the corrosion potential ( $\left.\mathrm{E}_{\text {corr }}\right)$ was ramped to a final potential of $20 \mathrm{mV}$ above $E_{\text {corr }}$ at a rate of $0.167 \mathrm{mV} / \mathrm{s}$. Linear fits were constrained to the potential range of $10 \mathrm{mV}$ below $E_{\text {corr }}$ to $10 \mathrm{mV}$ above $E_{\text {corr }}$. The Tafel constants, $\beta_{\mathrm{a}}$ and $\beta_{\mathrm{c}}$, were assumed to be $\pm 0.12 \mathrm{~V} / \mathrm{dec}$ ade. Corrosion rates were calculated using Equation 1

$$
C R(n m / y r)=k \frac{i_{\text {corr }}}{\rho} E W
$$

Where $\mathrm{k}$ is a conversion factor $\left(3.27 \times 10^{9} \mathrm{~nm} \cdot \mathrm{g} \cdot \mathrm{A}^{-1} \cdot \mathrm{cm}^{-1} \cdot \mathrm{yr}^{-1}\right), \mathrm{i}_{\text {corr }}$ is the measured corrosion current density in $\mathrm{A} / \mathrm{cm}^{2}, \mathrm{EW}$ is the equivalent weight, and $\rho$ is the density of Alloy $22\left(8.69 \mathrm{~g} / \mathrm{cm}^{3}\right)$. Assuming an equivalent dissolution of the major alloying elements as $\mathrm{Ni}^{2+}, \mathrm{Cr}^{3+}, \mathrm{Mo}^{6+}, \mathrm{Fe}^{2+}$, and $\mathrm{W}^{6+}$, the $\mathrm{EW}$ for Alloy 22 is 23.28 (ASTM G 102) [17]. Tests to assess the susceptibility of Alloy 22 to localized corrosion and passive stability were conducted using the cyclic potentiodynamic polarization technique (ASTM $\mathrm{G}$ 61) [17]. The potential scan was started $150 \mathrm{mV}$ below $E_{\text {corr }}$ at a set scan rate of 0.167 $\mathrm{mV} / \mathrm{s}$. The scan direction was usually reversed when the current density reached 5 $\mathrm{mA} / \mathrm{cm}^{2}$ in the forward scan. After the cyclic polarization tests the specimens were examined in an optical stereomicroscope at a magnification of 40 times to establish the mode of attack. A few specimens were also studied using a scanning electron microscope (SEM).

\section{RESULTS AND DISCUSSION}

\section{The Corrosion Potential ( $\left.\mathrm{E}_{\mathrm{corr}}\right)$}

Figure 1 shows the corrosion potential $\left(\mathrm{E}_{\mathrm{corr}}\right)$ of individual MA MCA samples of Alloy 22 in $5 \mathrm{M} \mathrm{CaCl}_{2}$ for six different temperatures as a function of the immersion time. The total immersion time was $24 \mathrm{~h}$ or $86,400 \mathrm{~s}$. Figure 1 shows that, after an initial transient period of approximately $3 \mathrm{~h}, \mathrm{E}_{\text {corr }}$ remained approximately constant as the time increased. Figure 1 also shows that the effect of the temperature on $\mathrm{E}_{\text {corr }}$ was non linear. That is, as the temperature increased from $45^{\circ} \mathrm{C}$ to $90^{\circ} \mathrm{C}, \mathrm{E}_{\text {corr }}$ decreased slightly (less than $40 \mathrm{mV})$. At the higher temperatures $\left(105^{\circ} \mathrm{C}\right.$ and $\left.120^{\circ} \mathrm{C}\right), \mathrm{E}_{\text {corr }}$ increased slightly (less than $30 \mathrm{mV}$ ). Similar non-linear relationships between $\mathrm{E}_{\text {corr }}$ and the temperature were 
reported before [7-8]. Overall, Figure 1 shows little impact of the temperature on $\mathrm{E}_{\text {corr }}$ of Alloy 22 in $5 \mathrm{M} \mathrm{CaCl}_{2}$. That is, for a range of temperature of $75^{\circ} \mathrm{C}$ (between $45^{\circ} \mathrm{C}$ and $120^{\circ} \mathrm{C}$ ) $\mathrm{E}_{\text {corr }}$ varied less than $60 \mathrm{mV}$. Figure 2 shows a compilation of $24 \mathrm{~h} \mathrm{E} \mathrm{E}_{\text {corr }}$ values for Alloy 22 in $\mathrm{CaCl}_{2}$ brines up to a concentration of $9 \mathrm{M}$ and a temperature of $150^{\circ} \mathrm{C}$. For example, the values of $\mathrm{E}_{\text {corr }}$ at $130^{\circ} \mathrm{C}$ are for $7 \mathrm{M} \mathrm{CaCl}_{2}$ and the value at $150^{\circ} \mathrm{C}$ is for $9 \mathrm{M}$ $\mathrm{CaCl}_{2}$. Moreover, the individual $\mathrm{E}_{\text {corr }}$ values in Figure 2 are for several types of specimens (MCA, Prisms, Discs and Rods) and for two types of material (MA and ASW). Some of the $\mathrm{E}_{\text {corr }}$ data in Figure 2 have been reported before [7-8]. Despite the variety of specimens and increasing chloride concentration, Figure 2 shows that in an approximately $100^{\circ} \mathrm{C}$-wide range of temperature, $E_{\text {corr }}$ of Alloy 22 in deaerated concentrated $\mathrm{CaCl}_{2}$ solutions was approximately the same and in the order of $-360 \mathrm{mV}$ SSC. In general, according to the Nernst equation, for a given environment and surface condition, $\mathrm{E}_{\mathrm{corr}}$ may be expected to decrease as the temperature increases. However, the fact that $\mathrm{E}_{\text {corr }}$ for Alloy 22 in concentrated $\mathrm{CaCl}_{2}$ brines does not change appreciably or linearly with the temperature, may suggest that $E_{\text {corr }}$ is controlled by the composition of the electrolyte. That is, the aggressiveness of the electrolyte may overshadow any temperature effect.

Figure 3 shows the individual $\mathrm{E}_{\text {corr }}$ values after $24 \mathrm{~h}$ immersion for Alloy 22 in solutions containing both $\mathrm{CaCl}_{2}$ and $\mathrm{Ca}\left(\mathrm{NO}_{3}\right)_{2}$ to a molar ratio $[\mathrm{Cl}-] /\left[\mathrm{NO}_{3}{ }^{-}\right]=10$. For comparative purposes Figure 3 also shows the average $E_{\text {corr }}$ values in pure $\mathrm{CaCl}_{2}$ solutions from Figure 2. Figure 3 shows that when $\mathrm{Ca}\left(\mathrm{NO}_{3}\right)_{2}$ is added to a $5 \mathrm{M} \mathrm{CaCl}_{2}$ solution, $\mathrm{E}_{\text {corr }}$ was almost indistinguishable from the values in pure $\mathrm{CaCl}_{2}$ up to approximately $100^{\circ} \mathrm{C}$. At the higher temperatures, $\mathrm{E}_{\text {corr }}$ of Alloy 22 in nitrate containing solutions was more positive than $\mathrm{E}_{\text {corr }}$ in pure $\mathrm{CaCl}_{2}$ solutions. Nitrate ions are oxidizing in nature and their presence in the solution may favor the formation of more stable chromium oxide film on the surface; therefore, raising $\mathrm{E}_{\text {corr }}$ in the nitrate containing solution. The fact that this increase in $E_{\text {corr }}$ was evident only at the higher temperatures (Figure 3) may suggest that the film formation process was kinetically controlled. It has been reported before that $\mathrm{E}_{\text {corr }}$ of five Alloy 22 rods in naturally aerated $5 \mathrm{M} \mathrm{CaCl}_{2}$ brine at $120^{\circ} \mathrm{C}$ stabilized at $-129 \pm 4 \mathrm{mV} \mathrm{SSC}$ after 30 to 350 days of testing [18]. That is, pure $\mathrm{CaCl}_{2}$ solutions in presence of air may also (in longer times) slightly increase $\mathrm{E}_{\text {corr }}$ from the $24 \mathrm{~h}$ values reported in Figure 2.

\section{$\underline{\text { Polarization Resistance and Corrosion Rate (CR) }}$}

Figure 4 shows the corrosion rate (CR) for Alloy 22 in concentrated $\mathrm{CaCl}_{2}$ and $\mathrm{CaCl}_{2}+\mathrm{Ca}\left(\mathrm{NO}_{3}\right)_{2}$ solutions as a function of the temperature. For both solutions, $\mathrm{CR}$ increased as the temperature increased. It seems that the effect of the temperature was higher for the pure $\mathrm{CaCl}_{2}$ solution. Figure 4 also shows that for all the tested temperatures, the corrosion rate was higher in the pure $\mathrm{CaCl}_{2}$ solution than in the $\mathrm{CaCl}_{2}+$ $\mathrm{Ca}\left(\mathrm{NO}_{3}\right)_{2}$ solution. This fact suggests that the addition of nitrate was not only beneficial about reducing the susceptibility of Alloy 22 to localized corrosion $[4,6]$ but it also reduces the corrosion rate of the alloy at the respective free corrosion potential. The maximum CR of $10 \mu \mathrm{m} /$ year (or $0.4 \mathrm{mpy}$ ) reported in Figure 4 can be considered very low for industrial standards. Moreover, this corrosion rate was measured in deaerated solutions only after $24 \mathrm{~h}$ of exposure. It is expected that in passivating alloys such as Alloy 22 , the corrosion rate will decrease as the time increases. The uniform corrosion 
rate of nickel alloys in near neutral chloride containing solutions is in general very low. Immersion tests for $96 \mathrm{~h}$ in boiling $4 \mathrm{M} \mathrm{NaCl}$ and synthetic seawater showed that the corrosion rate of nickel alloys N06600, N06825, N06455 and N10276 was below 0.1 mpy $(2.5 \mu \mathrm{m} / \mathrm{y})[19]$.

The data in Figure 4 seem to indicate that the corrosion rate peaks at about $120^{\circ} \mathrm{C}$ and then decreases as the temperature increases further. This could be associated with the reduced activity of water in the solution. The CR data at $\mathrm{T}>120^{\circ} \mathrm{C}$ were obtained in solutions containing more than $15 \mathrm{M}$ of theoretically dissociated species, which may greatly reduce the capacity of the solution to dissolve metallic ions from the alloy. That is, the theoretical concentration of pure water of $55 \mathrm{M}$ may be less than $5 \mathrm{M}$ in the brines reported here. The study of highly concentrated brines is outside the scope of this paper.

\section{Cyclic Polarizations (CP) and the Inhibitive Effect of Nitrate}

Figures 5 and 6 show the cyclic polarization curves for Alloy $22 \mathrm{MCA}$ specimens in deaerated $5 \mathrm{M} \mathrm{CaCl}_{2}$ at $30^{\circ} \mathrm{C}$ intervals (Figure 5 at $45^{\circ} \mathrm{C}, 75^{\circ} \mathrm{C}$, and $105^{\circ} \mathrm{C}$ and Figure 6 at $60^{\circ} \mathrm{C}, 90^{\circ} \mathrm{C}$, and $120^{\circ} \mathrm{C}$ ). At $45^{\circ} \mathrm{C}$ and $60^{\circ} \mathrm{C}$, there was some noise and small anodic peaks just above $+0.2 \mathrm{~V} \mathrm{SSC}$; however, the alloy maintained its passivity and the final polarized potential was above $1 \mathrm{~V}$ (Figures 5 and 6). At $45^{\circ} \mathrm{C}$ and $60^{\circ} \mathrm{C}$, the polarization curves did not show a hysteresis loop in the reverse scan. Figures 5 and 6 show that at $75^{\circ} \mathrm{C}, 90^{\circ} \mathrm{C}, 105^{\circ} \mathrm{C}$ and $120^{\circ} \mathrm{C}$ a passivity breakdown occurred at potentials lower than +0.2 V SSC. Moreover, at these four latter temperatures, the curves showed a hysteresis loop in the reverse scan. Stereomicroscope and SEM observations after the tests showed that the specimens were mostly free from localized attack at $45^{\circ} \mathrm{C}$ and $60^{\circ} \mathrm{C}$ and exhibited localized attack at $75^{\circ} \mathrm{C}$ and higher temperatures. Inspection of the samples under high magnification showed that a few of the samples tested at $45^{\circ} \mathrm{C}$ and $60^{\circ} \mathrm{C}$ exhibited features consistent with localized (crevice) attack. These corrosion features were rare, shallow and of a dull appearance. In all, there was a profound difference in the severity of the attack between 60 and $75^{\circ} \mathrm{C}$. At the latter and higher temperatures, the localized corrosion was not a typical attack in the form of pitting corrosion or crevice corrosion under the crevice former. The attack suffered by Alloy 22 in concentrated $\mathrm{CaCl}_{2}$ brines started at the crevice former/metal interface and progressed outward towards the solution. From the observation of the specimens it is apparent that this attack produced on the surface of the specimen a different type of electrolyte, which dissolved away a shallow layer of metal, typically in the direction of the gravity force. Figure 7 shows a SEM image of the boundary between a attacked and non attacked region of a specimen polarized in $5 \mathrm{M} \mathrm{CaCl}_{2}$ solution at $75^{\circ} \mathrm{C}$. Figure 7 also shows that the attack was shallow ( $<20 \mu \mathrm{m}$ deep), that is, the attack did not progress inward towards the thickness of the specimen. The shallow nature of localized attack in Alloy 22 polarized in chloride solutions has been reported before [20]. Direct evidence is not available on the nature of the corroding solution in contact with the attacked portions of the specimen at $T$ $>75^{\circ} \mathrm{C}$ (Figure 7); however, the crystallographic appearance of outlining grains and grain boundaries may suggest that a concentrated hydrochloric acid $(\mathrm{HCl})$ solution may have formed. Ni-Cr-Mo alloys such as N06022 show typically this type of crystallographic appearance when corroded in boiling $\mathrm{HCl}$ solutions [1,2]. 
Figures 8, 9 and 10 show comparatively the cyclic polarization curves of Alloy 22 in pure $\mathrm{CaCl}_{2}$ solutions and in $\mathrm{CaCl}_{2}+\mathrm{Ca}\left(\mathrm{NO}_{3}\right)_{2}$ solutions at $60^{\circ} \mathrm{C}, 90^{\circ} \mathrm{C}$ and $130^{\circ} \mathrm{C}$ respectively. At $130^{\circ} \mathrm{C}$ the base $\mathrm{CaCl}_{2}$ solution was $7 \mathrm{M}$; however, at all temperatures, the molar ratio $\left[\mathrm{Cl}^{-}\right] /\left[\mathrm{NO}_{3}{ }^{-}\right]$was 10 . At all the tested temperatures, the passive current density of Alloy 22 in the nitrate containing solution was lower than in the pure $\mathrm{CaCl}_{2}$ solution (Figures 8-10). At $60^{\circ} \mathrm{C}$, where Alloy 22 was free from the pervasive localized attack in pure $\mathrm{CaCl}_{2}$, the breakdown potential remained unchanged when nitrate was added to the solution. However, at $90^{\circ} \mathrm{C}$ where Alloy 22 suffered localized attack in pure $\mathrm{CaCl}_{2}$ solution, the breakdown potential increased and the specimen was mostly free from localized attack after the test (Figure 9). At $130^{\circ} \mathrm{C}$, the presence of nitrate raised the breakdown potential and changed the mode of attack. At this latter temperature (as well as at $105^{\circ} \mathrm{C}$ and $120^{\circ} \mathrm{C}$ ) the mode of attack changed from localized crystallographic type of dissolution (Figure 7) to a spotty type of attack having a lace like appearance (Figure 11). Future metallographic cross-section will determine the depth of the attack shown in Figure 11.

\section{Parameters from the Cyclic Polarization Curves}

In the polarization curves (e.g. Figures :5 and 6) there are several typical potentials. One is the potential for which the net applied cathodic and anodic currents are the same. Another typical potential is the breakdown potential for which the current density increases significantly and rapidly above the "passive" current density. Figures 5 and 6 show two arrows indicating the values of current density of $200 \mu \mathrm{A} / \mathrm{cm}^{2}$ and 1 $\mu \mathrm{A} / \mathrm{cm}^{2}$. Generally, the values of passive current density are between $1 \mu \mathrm{A} / \mathrm{cm}^{2}$ and 200 $\mu \mathrm{A} / \mathrm{cm}^{2}$. That is, in the forward scan, when the current density reaches $200 \mu \mathrm{A} . \mathrm{cm}^{2}$ the passivity of the alloy would have broken down. Similarly, when the current density in the reverse scan has reached $1 \mu \mathrm{A} / \mathrm{cm}^{2}$, the alloy would have regained its passive behavior prior to the breakdown. Hence, parameters can be extracted from the cyclic polarization curves that indicate the potentials at which the forward current density reached 200 $\mu \mathrm{A} / \mathrm{cm}^{2}$ (E200) and the reverse current density reached $1 \mu \mathrm{A} / \mathrm{cm}^{2}$ (ER1). These parameters would allow comparison among polarization curves without the clutter of superimposing too many curves. That is, just two parameters (E200 and ER1) would capture the basic shape of the potentiodynamic curves. The technique of selecting values of potential for fix current densities has been used before by other investigators $[5,13,20]$.

Figure 12 shows the average values of $E_{\text {corr }}$ and $E 200$ for Alloy 22 in $5 \mathrm{M} \mathrm{CaCl}_{2}$ and $5 \mathrm{M} \mathrm{CaCl}_{2}+0.5 \mathrm{M} \mathrm{Ca}\left(\mathrm{NO}_{3}\right)_{2}$ as a function of the temperature. These are average values from many specimens, including MCA, bars, prisms and discs. For all the temperatures tested, E200 for nitrate containing solutions was higher than E200 for pure chloride solutions. Figure 12 shows that $\mathrm{E} 200$ in pure $\mathrm{CaCl}_{2}$ dropped approximately 500 $\mathrm{mV}$ between $60^{\circ} \mathrm{C}$ and $75^{\circ} \mathrm{C}$, indicating that the resistance of Alloy 22 to localized corrosion has been drastically reduced at $75^{\circ} \mathrm{C}$. From $75^{\circ} \mathrm{C}$ to higher temperatures, the decrease of E200 was gradual approximately linear with the increase in temperature. Figure 12 also shows that when nitrate was added to the solution, the largest drop in E200 happened between $90^{\circ} \mathrm{C}$ and $105^{\circ} \mathrm{C}$, that is, the addition of nitrate to the solution moved

\footnotetext{
${ }^{1}$ The region of potentials between the corrosion potential and the breakdown potential is generally called the passive region of potentials. However, in certain tests carried out in aggressive environments such as 5 $\mathrm{M} \mathrm{CaCl}_{2}$ the value of current density at this region of potentials is too high to be called passive current density. 
the temperature of resistance to localized corrosion to higher temperatures (basically from $75^{\circ} \mathrm{C}$ to $105^{\circ} \mathrm{C}$ ). According to Figure 12 , the addition of nitrate in a molar ratio $\mathrm{CCl}^{-}$ ]$/\left[\mathrm{NO}_{3}{ }^{-}\right]=10$ delayed the occurrence of localized attack by approximately $25^{\circ} \mathrm{C}$. Moreover, even at temperatures where localized attack occurred in nitrate containing solutions $\left(\mathrm{T}>105^{\circ} \mathrm{C}\right.$ ), the potentials for E200 shifted to more positive values. The difference between the corrosion potential $\left(\mathrm{E}_{\text {corr }}\right)$ and the breakdown potential (e.g E200) may represent the extent of the passive region of potentials or the region of potentials to which Alloy 22 may be polarized without suffering localized corrosion. That is, in Figure 12 it can be seen that this difference $\Delta E=E 200-E_{\text {corr }}$ is larger in nitrate containing solutions than in pure chloride solutions in all the studied temperature range.

Figure 13 shows the average values of $E_{\text {corr }}$ and ER1 for Alloy 22 in $5 \mathrm{M} \mathrm{CaCl}_{2}$ and $5 \mathrm{M} \mathrm{CaCl}_{2}+0.5 \mathrm{M} \mathrm{Ca}\left(\mathrm{NO}_{3}\right)_{2}$ as a function of the temperature. A similar analysis can be done as for E200 above. For all the temperatures tested ER1 for nitrate containing solutions was higher than for pure chloride solutions. The transition potentials for ER1 between no-localized attack to localized attack was less dramatic than for E200 (Figure 12). Figure 13 shows two regions of linear dependences between ER 1 and temperature, both for the pure chloride and the nitrate containing solutions. The difference $\triangle E=E R 1-$ $E_{\text {corr }}$ was positive for all temperatures both for pure chloride solutions and solutions containing nitrate, even though this difference was larger for the latter (Figure 13). Lastly, $\triangle \mathrm{E}$ for $\mathrm{ER} 1$ values was smaller (Figure 13) than for E200 values (Figure 12) suggesting that the use of ER1 as a parameter to determine the range of susceptibility to localized corrosion may be more conservative.

\section{CONCLUSIONS}

1. The corrosion potential of Alloy 22 in 5-9 $\mathrm{M} \mathrm{CaCl}_{2}$ was approximately $-360 \mathrm{mV} \mathrm{SSC}$ between $45^{\circ} \mathrm{C}$ and $150^{\circ} \mathrm{C}$.

2. The uniform corrosion rate of Alloy 22 measured using polarization resistance was lower in nitrate containing solutions than in pure calcium chloride solutions.

3. The addition of nitrate to calcium chloride solutions decreased the anodic passive current density of Alloy 22.

4. Using cyclic polarization curves, Alloy 22 was found mostly not susceptible to localized corrosion in $5 \mathrm{M} \mathrm{CaCl}_{2}$ at $45^{\circ} \mathrm{C}$ and $60^{\circ} \mathrm{C}$.

5. Alloy 22 was found to be significantly susceptible to localized corrosion in $5 \mathrm{M}$ $\mathrm{CaCl}_{2}$ at $75^{\circ} \mathrm{C}$ and higher temperatures. The higher the temperature the lower the breakdown potential.

6. The use of parameters such as E200 and ER1 are valuable tools to assess the susceptibility of Alloy 22 to suffer localized corrosion in calcium chloride brines.

\section{ACKNOWLEDGMENTS}

This work was performed under the auspices of the U. S. Department of Energy by the University of California Lawrence Livermore National Laboratory under contract $\mathrm{N}^{\circ} \mathrm{W}-$ 7405-Eng-48. The work was supported by the Yucca Mountain Project, which is part of the DOE Office of Civilian Radioactive Waste Management (OCRWM). 


\section{REFERENCES}

1. R. B. Rebak in Corrosion and Environmental Degradation, Volume II, p. 69, Wiley-VCH, Weinheim, Germany (2000).

2. R. B. Rebak and P. Crook, Advanced Materials and Processes, February 2000.

3. Yucca Mountain Science and Engineering Report, U. S. Department of Energy, Office of Civilian Radioactive Waste Management, DOE/RW-0539, Las Vegas, NV, May 2001.

4. G. M. Gordon, Corrosion, 58, 811 (2002).

5. B. A. Kehler, G. O. Ilevbare and J. R. Scully, Corrosion, 1042 (2001).

6. K. J. Evans and R. B. Rebak in Corrosion Science - A Retrospective and Current Status in Honor of Robert P. Frankenthal, PV 2002-13, p. 344-354 (The Electrochemical Society, 2002: Pennington, NJ).

7. G. O. Ilevbare, PVP-Vol. 449, Transportation, Storage and Disposal of Radioactive Materials - 2002, p. 55 (ASME, 2002: New York, NY).

8. S. D. Day, K. J. Evans and G. O. Mevbare, paper presented at the $202^{\text {nd }}$ Electrochemical Society Meeting, Salt Lake City, UT, 20-24 October 2002 (to be published by The Electrochemical Society, 2003: Pennington, NJ).

9. L. L. Wong, D. V. Fix, J. C. Estill, R. D. McCright and R. B. Rebak, Presented at the Fall Meeting of the Materials Research Society, Boston, MA 2-5 December 2002 (to be published by MRS, 2003: Warrendale, PA).

10. P. D. Hailey and G. E. Gdowski, Presented at the Fall Meeting of the Materials Research Society, Boston, MA 2-5 December 2002 (to be published by MRS, 2003: Warrendale, PA).

11. O. Pensado, D. S. Dunn and G. A. Cragnolino, Presented at the Fall Meeting of the Materials Research Society, Boston, MA 2-5 December 2002 (to be published by MRS, 2003: Warrendale, PA).

12. N. S. Meck, P. Crook, S. D. Day and R. B. Rebak, Corrosion/03, Paper 03682 (NACE International, 2003: Houston, TX).

13. D. S. Dunn, L. Yang, Y. - M. Pan and G. A. Cragnolino, Corrosion/03, Paper 03697 (NACE International, 2003: Houston, TX).

14. A. I. Pulvirenti, K. M. Needham, M. A. Adel-Hadadi, E. J. Bishop, A. Barkatt, C. R. Marks and J. A. Gorman, Corrosion/03, Paper 03693 (NACE International, 2003: Houston, TX).

15. ASTM Standard D 98 Volume 04.03 (The American Society for Testing and Materials, 2003: West Conshohocken, PA).

16. AWWA Standard B550 (American Water Works Association, 2000: Denver, $\mathrm{CO})$.

17. ASTM Standards G 5, G 48, G 59, G 61 and G 102, Volume 03.02 (The American Society for Testing and Materials, 2003: West Conshohocken, PA).

18. J. C. Estill, G. A. Hust and R. B. Rebak, Corrosion/03, Paper 03688 (NACE International, 2003: Houston, TX).

19. Database from Haynes International Inc. (Kokomo, IN).

20. B. A. Kehler, G. O. Ilevbare and J. R. Scully in "Localized Corrosion" Proc. Research Topical Symposium (NACE International, 2001: Houston, TX). 


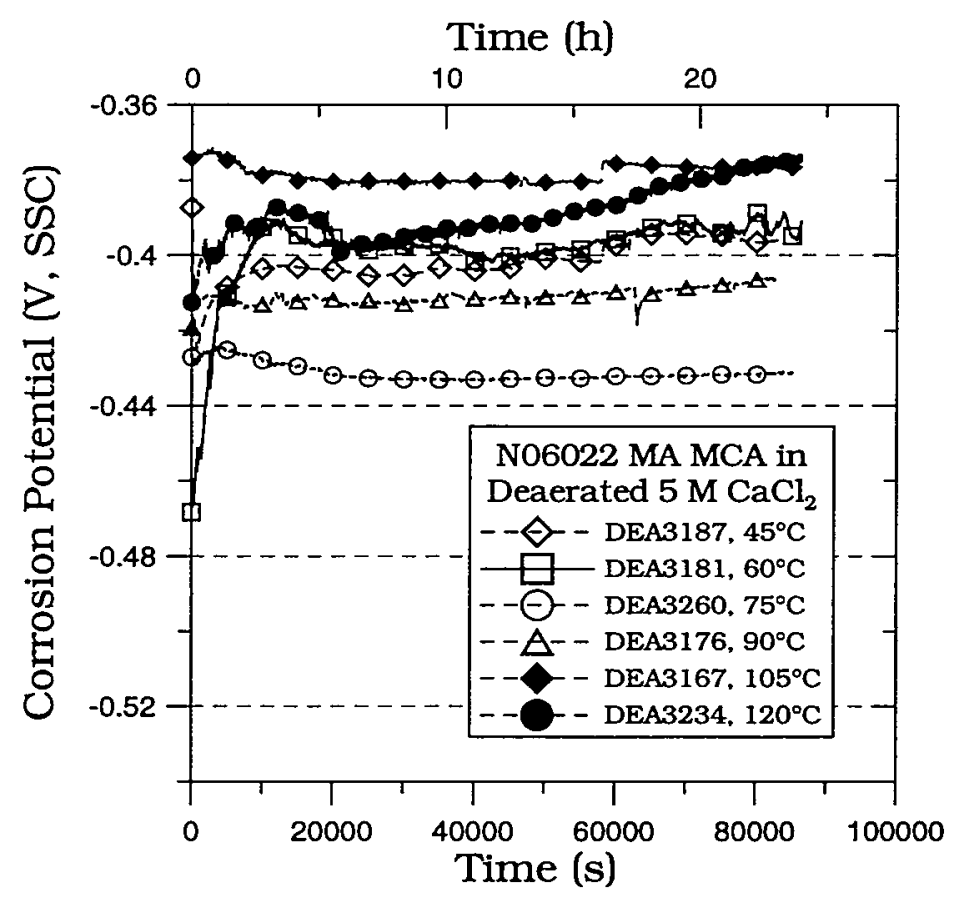

Figure 1: Corrosion Potential Evolution for MCA Alloy 22 samples in $5 \mathrm{M} \mathrm{CaCl}_{2}$

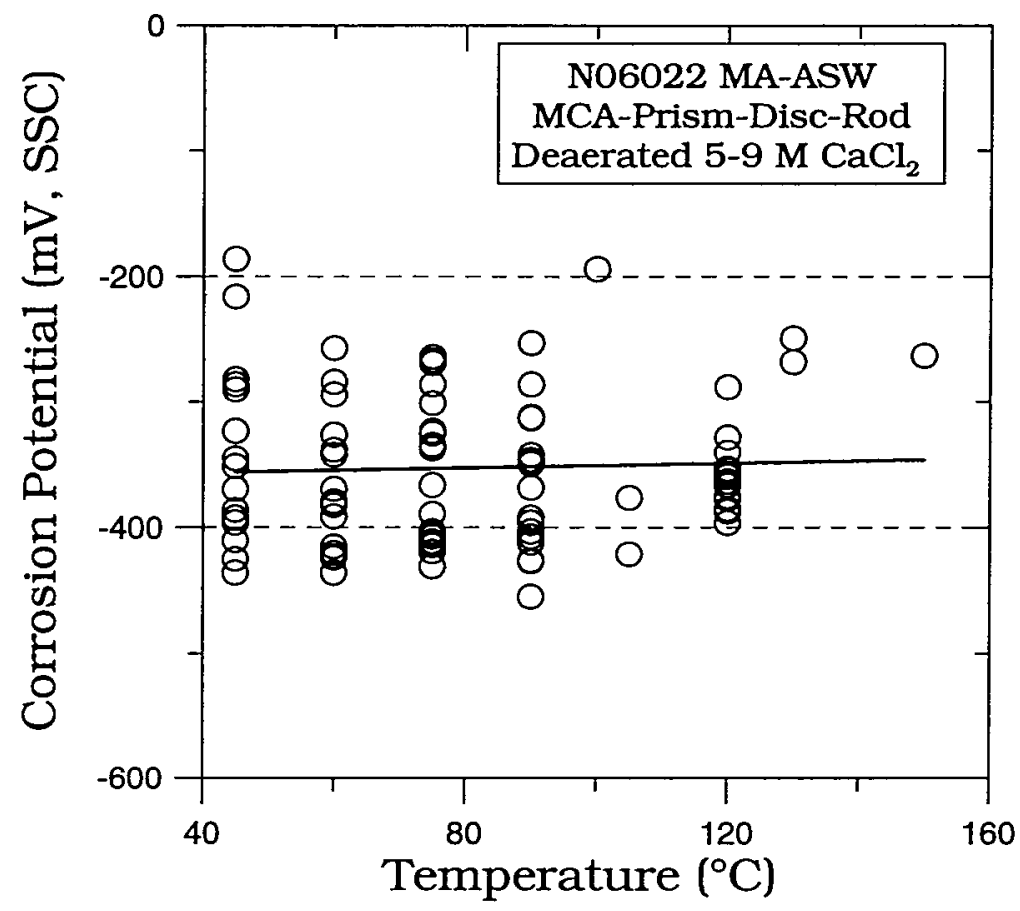

Figure 2: $24 \mathrm{~h}-\mathrm{E}_{\text {corr }}$ for Alloy 22 in 5-9 $\mathrm{M} \mathrm{CaCl}_{2}$ as a function of the Temperature. The line is a linear fit. 


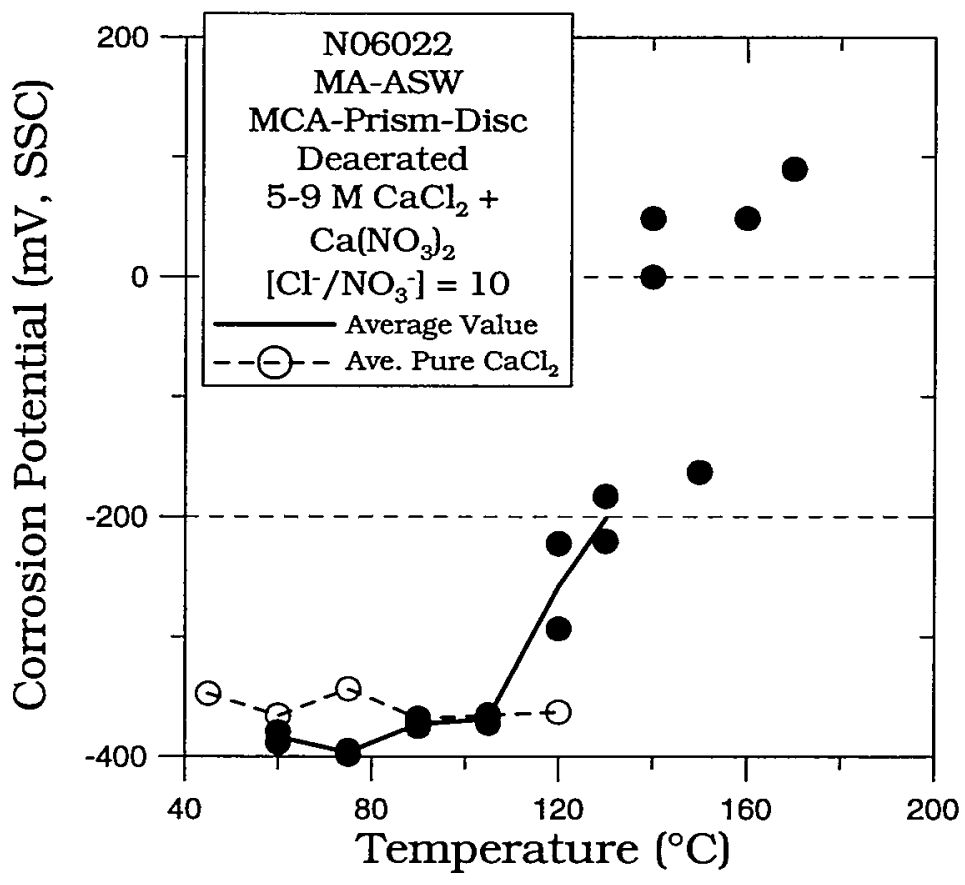

Figure 3: $\mathrm{E}_{\text {corr }}$ for Alloy 22 in 5-9 $\mathrm{M} \mathrm{CaCl}_{2}+\mathrm{Ca}\left(\mathrm{NO}_{3}\right)_{2}$ to a molar ratio $[\mathrm{Cl}] /\left[\mathrm{NO}_{3}{ }^{-}\right]=10$ as a function of the Temperature.

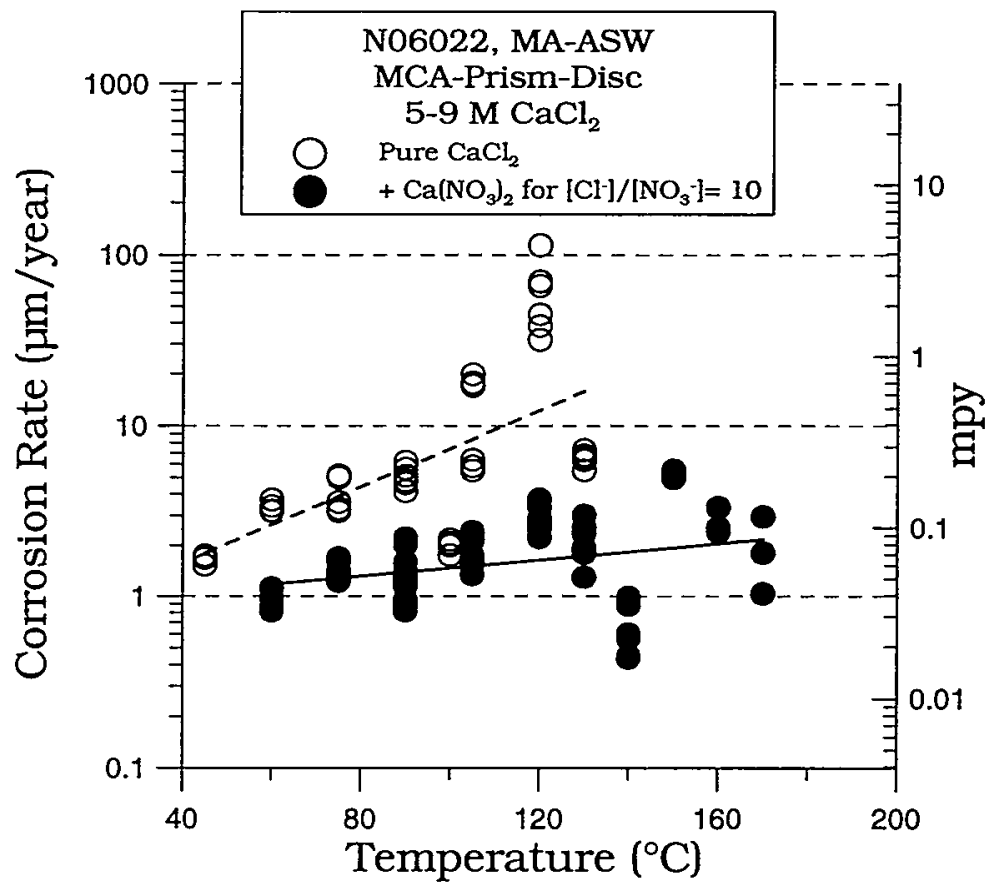

Figure 4: Corrosion Rates from Polarization Resistance Tests. 


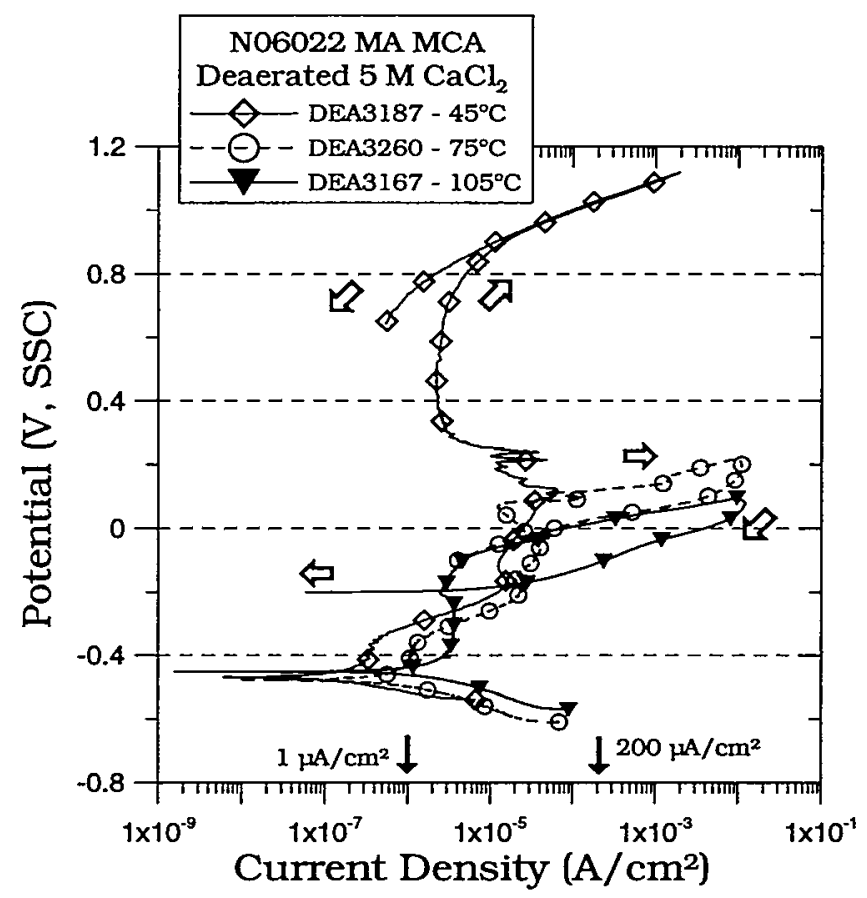

Figure 5: Cyclic polarization for Alloy 22 in $5 \mathrm{M} \mathrm{CaCl}_{2}$ at 45,75 and $105^{\circ} \mathrm{C}$.

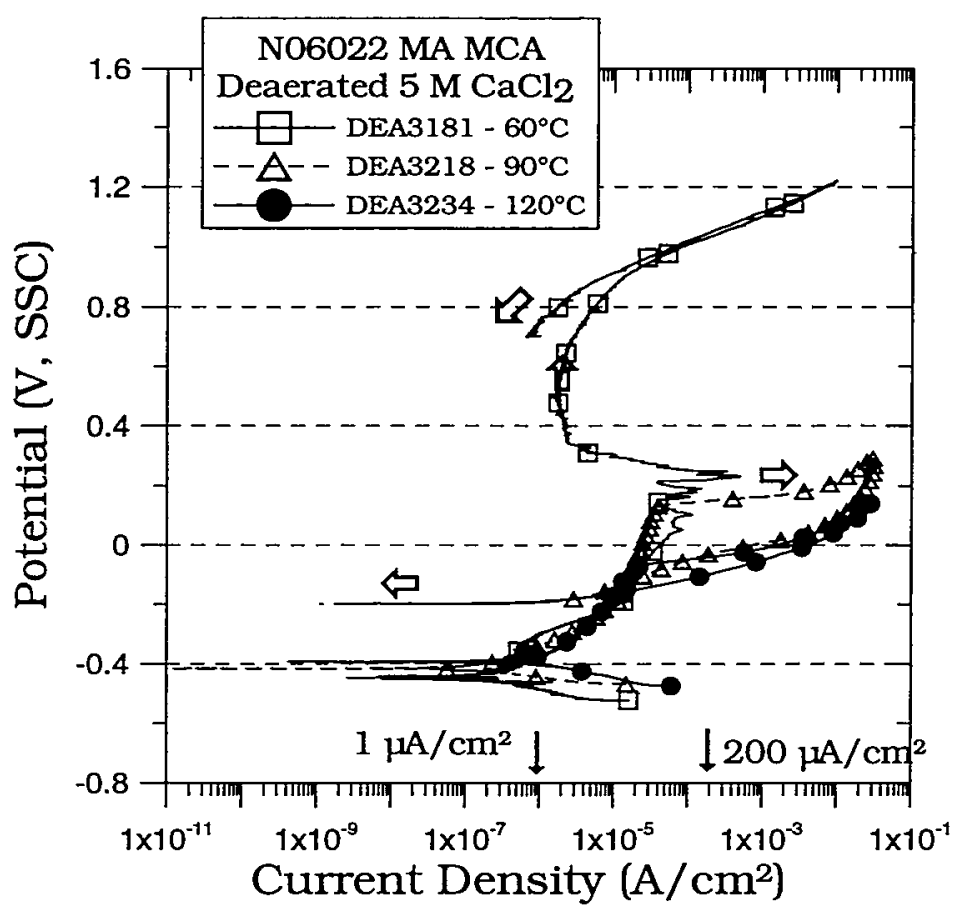

Figure 6: Cyclic polarization for Alloy 22 in $5 \mathrm{M} \mathrm{CaCl}_{2}$ at 60,90 and $120^{\circ} \mathrm{C}$. 


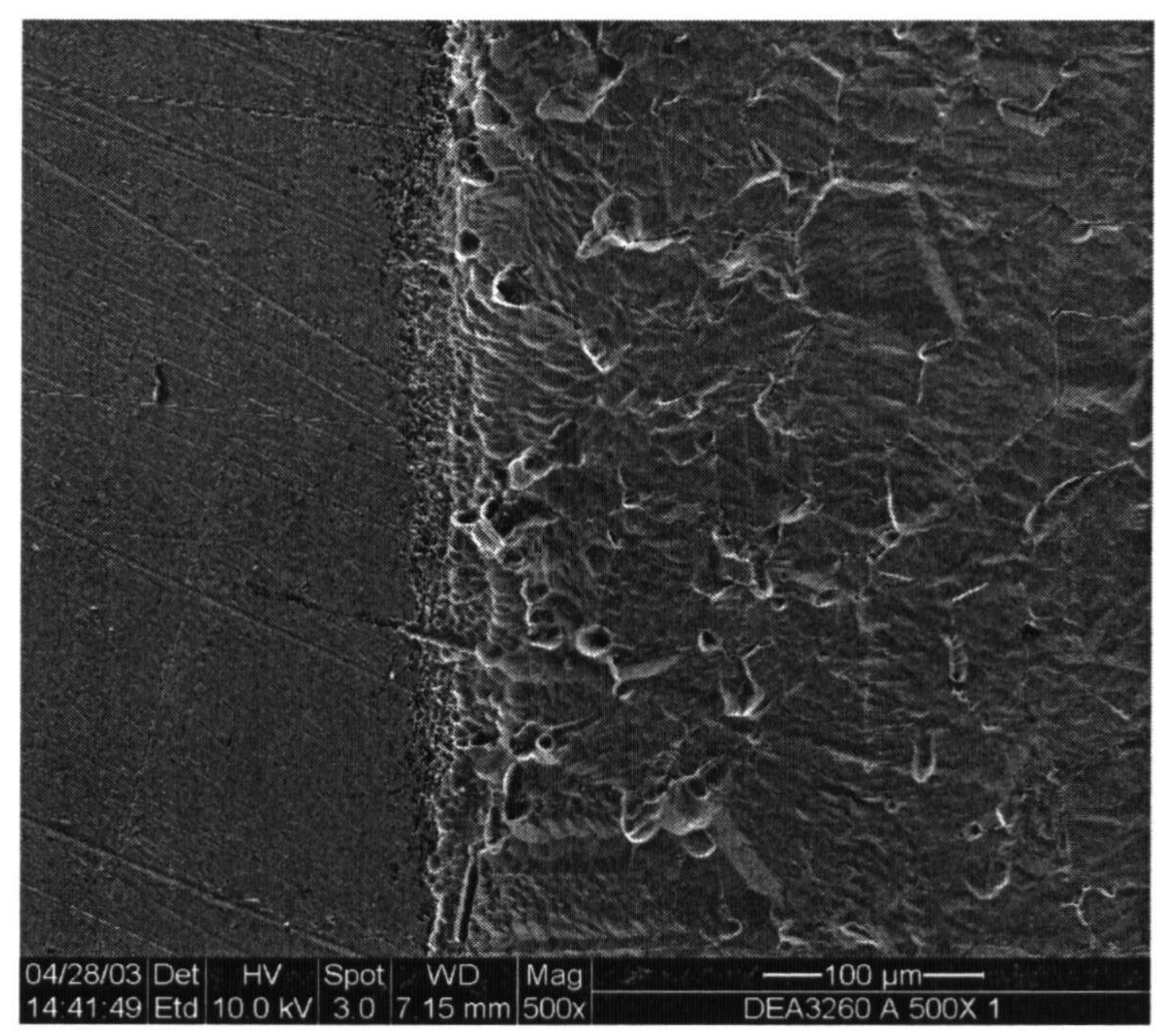

Figure 7: SEM image of Alloy 22 after cyclic polarization in $5 \mathrm{M} \mathrm{CaCl}_{2}$ at $75^{\circ} \mathrm{C}$. The left part of the specimen was unattacked and the right part suffered crystallographic like dissolution, probably due to the presence of $\mathrm{HCl}$.

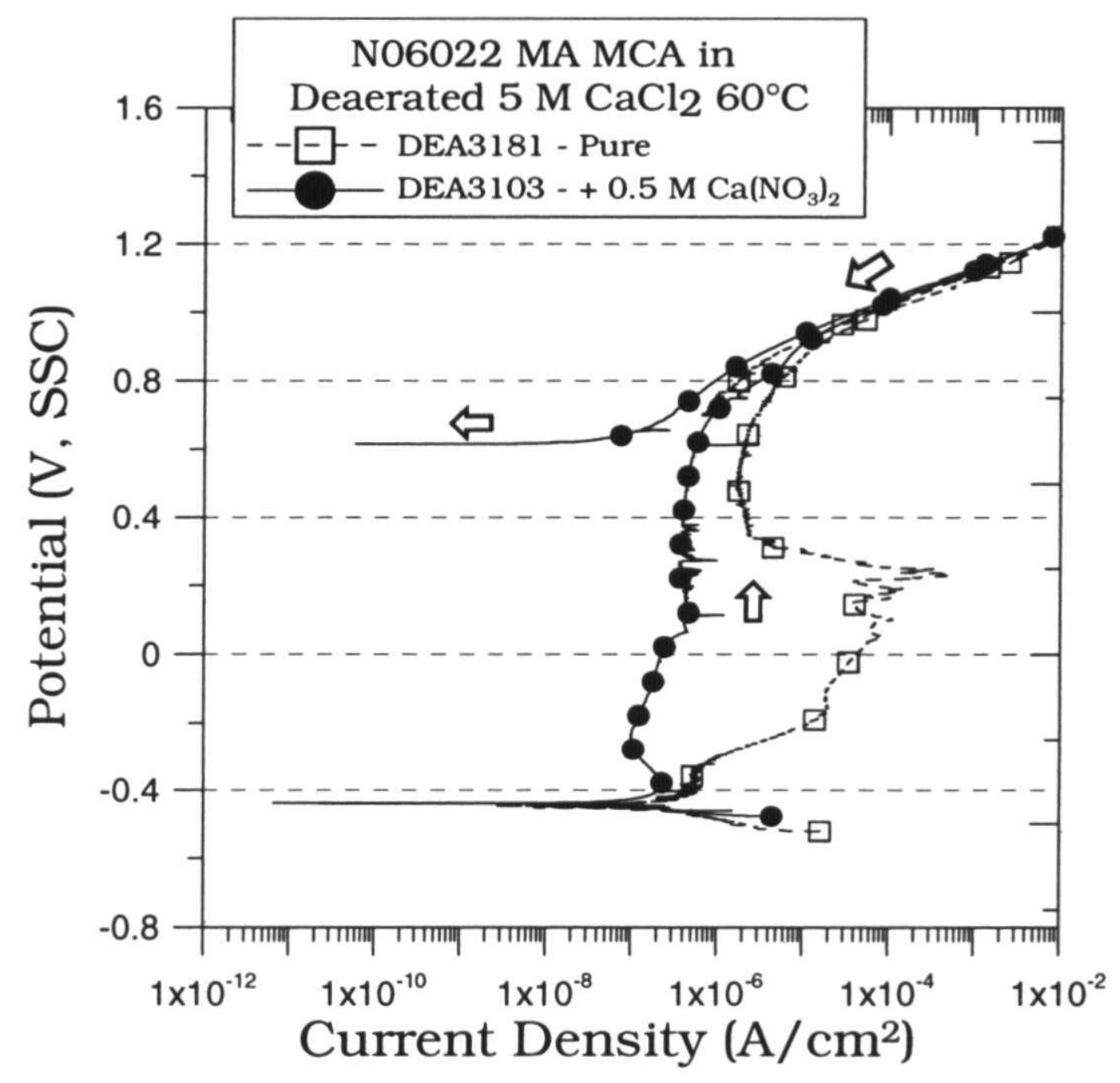

Figure 8: Cyclic polarization curves for Alloy 22 in $5 \mathrm{M} \mathrm{CaCl}_{2}$ and $5 \mathrm{M} \mathrm{CaCl}_{2}+0.5 \mathrm{M}$ $\mathrm{Ca}\left(\mathrm{NO}_{3}\right)_{2}$ at $60^{\circ} \mathrm{C}$. 


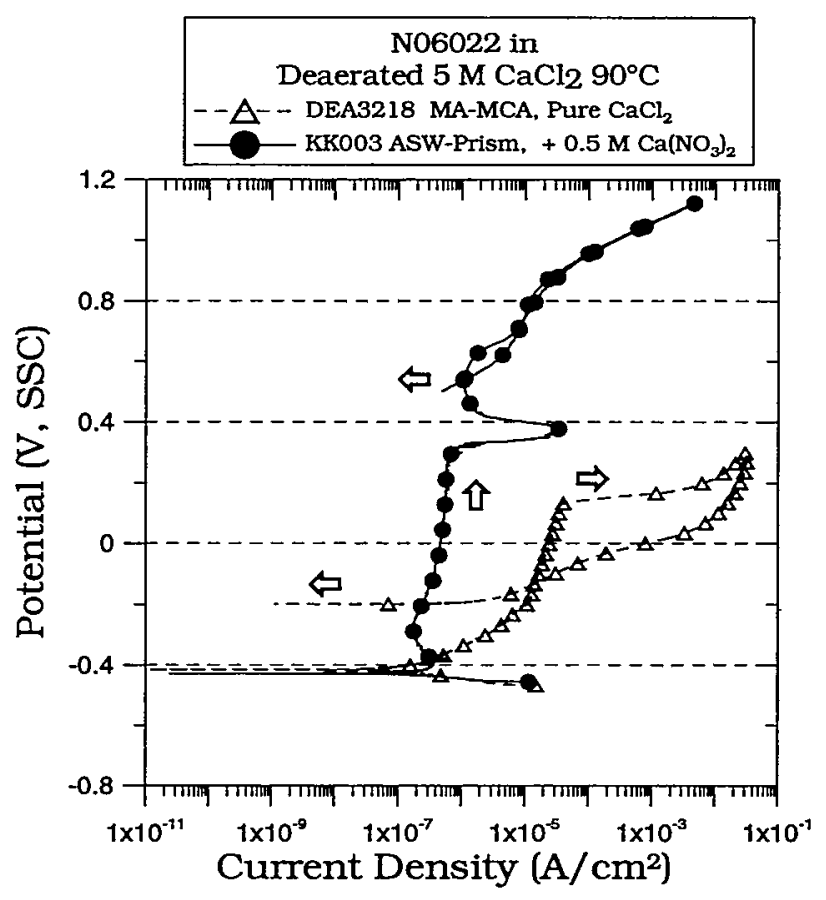

Figure 9: Cyclic polarization curves for Alloy 22 in $5 \mathrm{M} \mathrm{CaCl}_{2}$ and $5 \mathrm{M} \mathrm{CaCl}_{2}+0.5 \mathrm{M}$ $\mathrm{Ca}\left(\mathrm{NO}_{3}\right)_{2}$ at $90^{\circ} \mathrm{C}$.

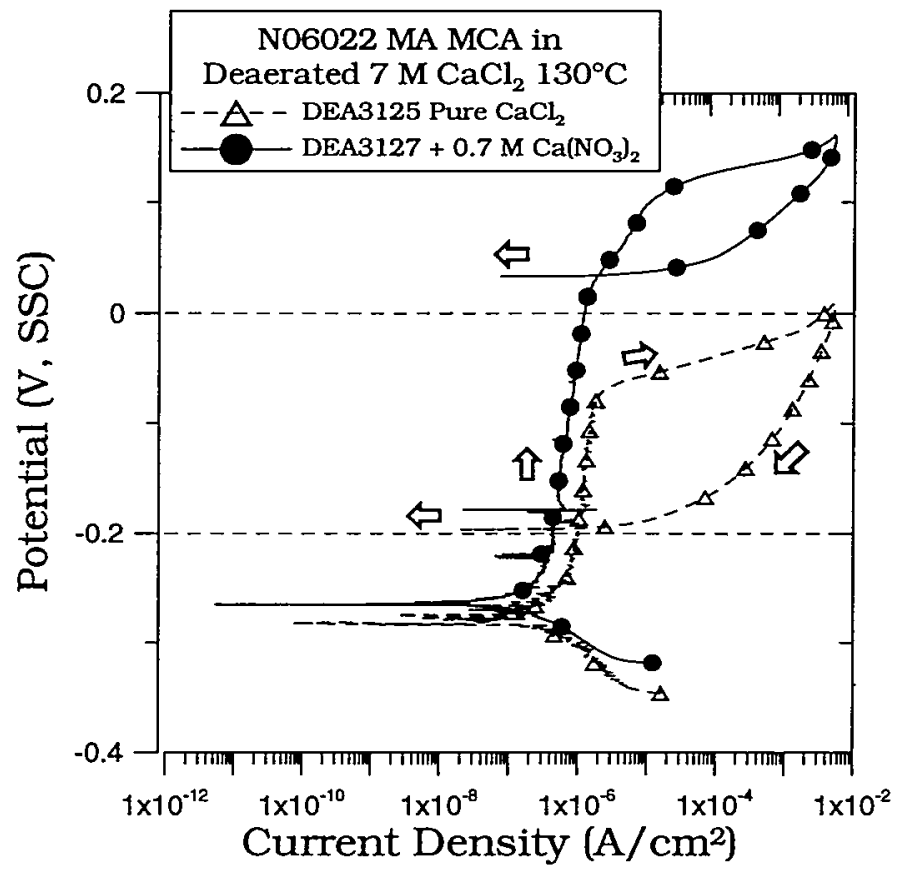

Figure 10: Cyclic polarization curves for Alloy 22 in $5 \mathrm{M} \mathrm{CaCl}_{2}$ and $7 \mathrm{M} \mathrm{CaCl}_{2}+0.7 \mathrm{M}$ $\mathrm{Ca}\left(\mathrm{NO}_{3}\right)_{2}$ at $130^{\circ} \mathrm{C}$. 


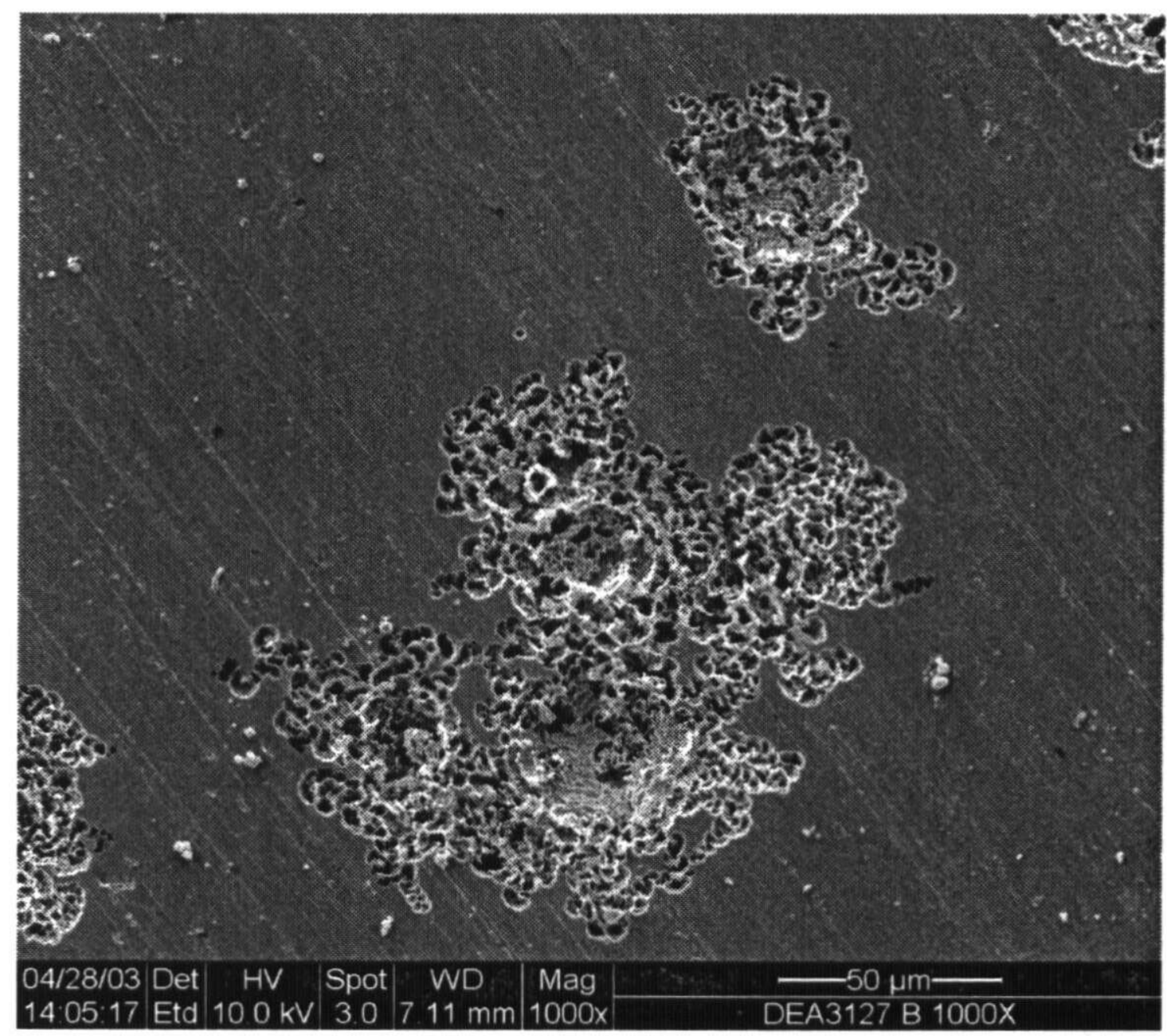

Figure 11: SEM image of Alloy 22 after cyclic polarization in $7 \mathrm{M} \mathrm{CaCl}_{2}+0.7 \mathrm{M}$ $\mathrm{Ca}\left(\mathrm{NO}_{3}\right)_{2}$ at $130^{\circ} \mathrm{C}$. The attack in solutions containing nitrate at temperatures $>100^{\circ} \mathrm{C}$ have a shallow lacy appearance.

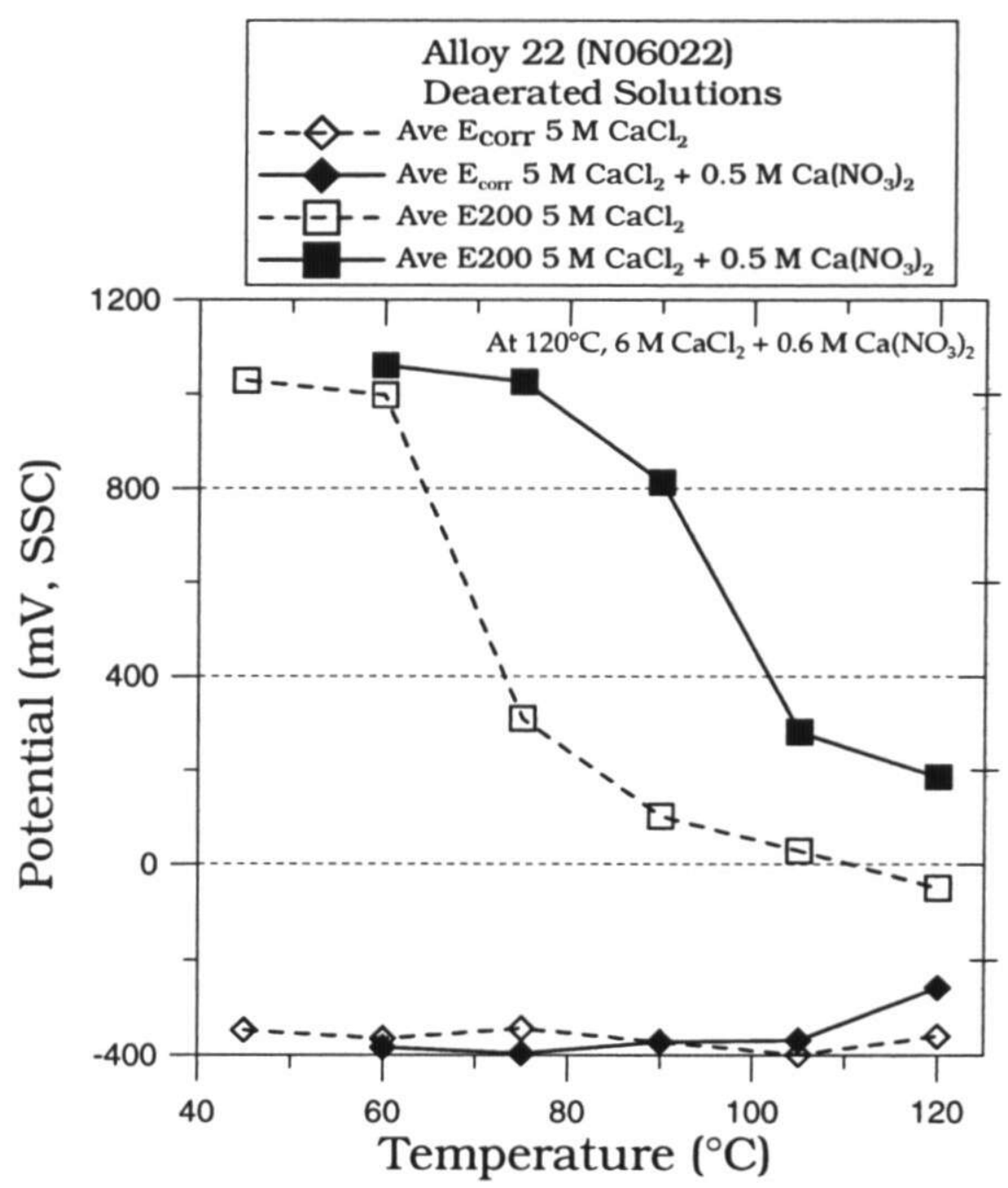

Figure 12: Average values of $\mathrm{E}_{\text {corr }}$ and E200 for Alloy 22. 


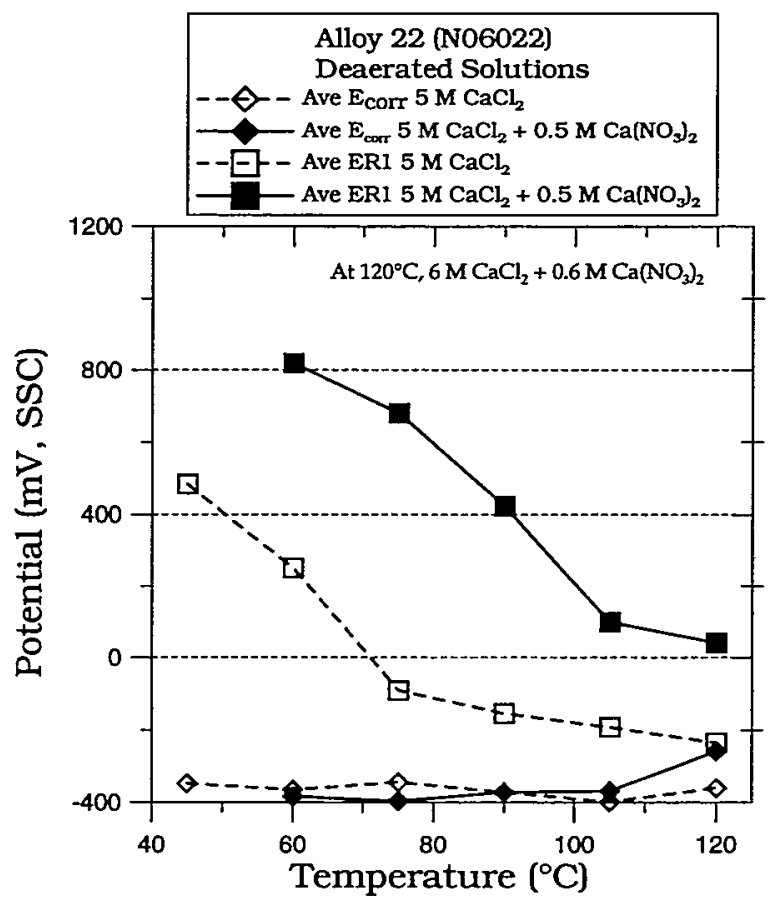

Figure 13: Average values of $E_{\text {corr }}$ and ER1 for Alloy 22. 